\title{
Regulating Petroleum Industry and Revenues: What Does Norway Get Out of the Petroleum Industry?
}

\author{
Noralv Veggeland (Professor) \\ Department of Economics and Organizational Science \\ Lillehammer University College \\ Postboks 952, 2604, Norway
}

Tel: 47-6128-8351 E-mail: noralv.veggeland@hil.no

Received: November 1, 2011

Accepted: November 23, 2011

Published: February 1, 2012

doi:10.5539/ijbm.v7n3p64

URL: http://dx.doi.org/10.5539/ijbm.v7n3p64

\begin{abstract}
The Norwegian Ministry of Petroleum and Energy (MPE) has from the beginning of the discovery of petroleum heavily regulated the production, transport, sale and revenues of oil and gas. The financial Government Pension Fund - Global was established, and later ethical guidelines have strictly regulated the Fund's foreign investments. The regulations are manifold and complex, which complicate both national and global implementations. This study shows that strong political will has made the adherence to the regulations successful. There remains one question, however: what do Norwegians themselves get out of the financial savings, besides a modest interest and dividend yield? The export surplus is said to be so large that spending more than a small fraction at home would cause inflation. The study elaborates the dilemma: public infrastructure represents the largest capital expenditure in almost every country, yet little trace of its economic role appears today in Norwegian infrastructure accounts.
\end{abstract}

Keywords: Petroleum revenues, Pension Fund, Regulation, Investment dilemmas

\section{The emergence of the Norwegian petroleum sector}

Petroleum was discovered in the North Sea in 1969. Production began in June 1971, and in the following years a number of major offshore petroleum discoveries were made all the way up along the economic zone to the Barents Sea. Today, there are more than 50 fields in production on the Norwegian continental shelf. But this development began earlier than that.

In 1962, Philips Petroleum sent an application to the Norwegian Government in order to explore oil opportunities in the North Sea. The international company asked for a license for the part of the North Sea that could possibly be included in the Norwegian shelf. The offer was for $\$ 160000$ per month (Veggeland, 2009). The Government interpreted the offer as the company's attempt to secure exclusive rights and thus it did not accept. It was out of question for the authorities, then, to allow a single company to monopolise the shelf. A regulatory policy was formulated; if the areas were to be opened for exploration, then more companies had to be involved. Moreover, Norway was at that time confronted with two main challenges: the lack of test seismic and drilling competence and capacity and the lack of international recognition of its ownership.

In May 1963, the Government proclaimed sovereignty on the Norwegian continental shelf. New regulations determined both that the Norwegian State was the sole owner of any natural resources and that only the Government is authorised to allocate licenses for exploration and production. Soon afterwards, companies were given the opportunities to test the potential for exploration. The licenses only included the rights to perform seismic surveys but not drilling. International agreements on dividing the continental shelf according to the median-line principle were reached in 1965. The first well was drilled in the summer of 1966, but nothing was found. Then, with the discovery of the Ekofisk oil field in 1969, and the Norwegian petroleum adventure really began economically. An adjusted regulatory petroleum regime was properly established and has ever since been crucial for developments and taming processes of a vulnerable sector.

\subsection{Petroleum revenues}

Norway ranks as the world's third largest oil exporter and the shrinking seventeenth largest oil producer 2009. In 
2004, Norway was the third largest gas exporter, and the seventh largest gas producer. In 2010 it changed to the world's second-biggest gas exporter. Saudi Arabia and Russia are at the top of the lists of exporters and producers.

The Ministry of Petroleum and Energy (MPE) has from the very beginning strongly regulated the production, transport, and sale of oil and gas. Despite that the European market in this economic field has become liberalised in the wake of the Single Market and several European Union (EU) directives, and Norway as a European Economic Area (EEA) country has been a part of this liberalisation, the MPE has still maintained extensive control (Austvik, 2003). It is the responsibility and duty of the MPE to submit concessions and to appoint delivery fields bound by contracts, as well as to approve commercial agreements. Although the political authorities - the Government and the Parliament (Stortinget) - make the decisions, the Ministry of Petroleum and Energy together with the Ministry of Finance are required to give expert advice before decisions are made and executed. The regulatory body of the Norwegian Petroleum Directorate (Oljedirektoratet) is not really a proper self-regulatory arm's-length governmental agency but an external administration with extended authorisation.

It is easy to understand that petroleum revenues have contributed significantly both to the economic growth in a small country like Norway and to the financing of an expensive welfare state of the Nordic type of universal social benefits (Veggeland, 2007). In 30 years of operation, the petroleum industry has created values of about USD 1.3 billion, now probably worth much more due to quickly rising oil and gas prices after that period. The petroleum sector accounts for about 25 per cent of value creation in the country. This is twice the value creation of the domestic manufacturing industry which makes the petroleum industry Norway's largest and most important industry. A high oil price and a sustained high level of activity make the basis for high value creation in the industry. Estimates 2010 show that the industry is contributing with more than NOK 311 billion to the Treasury. This is equivalent to more than 10 transport budgets.

The large petroleum revenues, as shown in Tab. 1, have resulted in substantial financial assets in what is now called the Government Pension Fund. The total returns on the Government Pension Fund Global (GPFG) in 2010 were good while the net real return will slow down; to a calculated minus $-2.4 \%$ in 2030 (see below), due to rising inland welfare costs. The overall results of the last years of production show that the large losses during the financial crisis has been more than compensated by the gains made in the subsequent market upswing, as shown in Tab. 1. One important reason is that the Government held on firmly to the long-term investment strategy.

In fact, according to the Norwegian Ministry of Finance (National budget, 2008), the Pension Fund - Global is among the largest and fastest growing funds in the world, rising from the value of USD 373 billion in 2007, Tab. 1, to about USD 584 bn in 2010, and is expected to be continuing growing.

\subsection{The Norwegian Government Pension Fund - Global: The Net Cash Flow}

The purpose of the Government Pension Fund is both to facilitate the governmental savings necessary to meet the rapid rise in public pension expenditures, as Figure 1 shows below, because of an increasing rate of ageing people in the coming years, and to make the long-term management of petroleum revenues effective for Norwegian interests.

Figure1 graphs the growth of revenues from the Norwegian petroleum industries as net cash flow in per cent of the GDP, reaching 25 per cent in 2006. According to prognoses, owing to the aging population and rising pension expenditures, this net cash flow as a per cent of the GDP is supposed to fall sharply after 2010.

Figure 1 also indicates that the net cash flow to the GPFG is expected to fall during the years ahead. While the share in 2010 was about $5 \%$, Tab. 1, is this figure expected to pass zero in 2020 , and become minus $2.4 \%$ in 2030 . A practical consequence of this fall of the net cash flow is that the Government must withdraw money from the Fund its self, which indicates that GPFG is enforced to reduce its activity as an international shareholder because of liquidity need.

Additionally, Figure 1 also reveals another fact: the fall of the net cash flow from petroleum in the beginning of the 1990s. Norway has employed Keynesian instruments to implement a policy of general government surplus. Heavy governmental budgets and the short-term recession of the early 1990s created a deficit in the fiscal budget for a period, which is reflected by the net cash flow curve of Fig. 1. Actually, the years it lasted were the only years since World War II when Norway had budget deficits on a general basis. The international financial crisis which came up in USA in 2008, and later on spread to Europe, in fact has so far (2011) had only minor effect on Norwegian economic policy, and petroleum policy in particular. Revenues from oil and gas have been stable high, and the path of the net cash flow indicated in Figure 1 has been followed. The shrinking trend is caused by increasing public welfare service costs, not by deficits caused by the crisis. Table 1 indicates an increase in total return, from $4.1 \%$ in 2007 to $5 \%$ in 2010 . 
By the end of the 1990s, surpluses on the central state budgets were statistically predicted to grow substantially owing to increasing petroleum revenues. This prediction convinced the Government that some sort of formal fiscal guidelines were needed to regulate effective demand and in order to restore control over inflation and employment (Ministry of Finance Report, 2006-2007). Large surpluses in public finances made the government and parliament to raise the demand-side of the economy, for example, the welfare or infrastructure sectors.

A regulatory regime solution was chosen, see Figure 2 shows below. The following fiscal guidelines were introduced in 2001 (Eriksen, 2006, p. 9):

- The use of petroleum revenues over the Government budget should be gradually phased into the economy approximately in pace with an estimated 4 percent real return on the assets in the Pension Fund - Global'.

- $\quad$ 'The actual regulatory implementation of fiscal policy, should, however, also' take into account business cycle fluctuations'

- 'The automatic stabilizers should have room to work'.

These fiscal guidelines were followed up with formal monetary policy rules targeting stability in the domestic and international economic market. A new regulation for monetary policy was established in 2001 in a white paper to the parliament (Report No. 29, 2000-2001). The Norwegian Central Bank, which implements the operational monetary policy, was instructed to aim for:

- Low and stable inflation, defined as an annual increase in consumer prices that remain close to $2 \frac{1 / 2}{2}$ per cent over time.

Actually, since 2001 until 2011 the inflation rate has remained stable at $21 / 2$ percent annually. The Government Pension Fund was formally established in 2006 and consists of two parts: 'The Government Pension Fund Global', which is a continuation of the Petroleum Fund, and 'The Government Pension Fund - Norway', which was previously known as the National Insurance Scheme Fund.

\subsection{Organizational arrangements}

The Ministry of Finance is responsible for the management of the Government Pension Fund. The Norwegian Central Bank carries out the operational management of the Pension Fund - Global. The Bank is an arm's-length agency regulated by the government and invests the Fund's capital in bonds and equities outside of Norway in accordance with guidelines issued by the Ministry, as Figure 2 shows. The operational management of the Pension Fund - Norway is carried out by 'Folketrygdfondet' as part of the system of social security.

Figure 2 shows the relations and mechanisms integrating the petroleum revenues and the ordinary budget of Norwegian Government, and the separation of governance in a regulatory state order. The Ministry of Finance is 'steering without rowing'; the arm's-length regulatory bodies do the 'rowing'.

In fact, in 1994, with Norwegian approval of the European Economic Agreement (EEA) that gave access to the Single European Market, the State's participation in the petroleum operation began to take place in the deregulated European petroleum market. In 1997, the EU introduced the principle of 'Third Party Access' (TPA) to the transmission pipelines, splitting companies' functions as transporters and wholesalers (Austvik, 2003). The TPA directive (often called the 'Gas Directive') was approved for implementation in 2000.

Norway as a participant of the Single Market through the EEA agreement had to reorganise the petroleum apparatus in a regulatory direction i.e., conforming to directives to split companies, extending the exposure to competition, and establishing a wide range of arm's-length control bodies as part of the regulatory regime.

Accordingly, the involvement of the State in the petroleum industry already split into two arm's-length bodies as private-law agencies (PLBs), Statoil ASA, the exploration and production corporation but controlled by the State as the main shareholder, and the State's Direct Financial Interest (SDFI). The SDFI arrangement was established in 1985, and requires the State to pay a share of all investments and operating costs in projects on the Norwegian continental shelf, which corresponds to its direct financial interest (Austvik, 2007).

In the other direction, the government receives accordingly a share of revenues from the sale of production and other income sources. The cash flow from the SDFI will continue to account for a significant proportion of the State's revenues from petroleum activities in the years ahead. One significant consequence of the EU's TPA directive (the Gas Directive) was the establishment of a number of the state-owned arm's-length, 'unelected' bodies. One of those was Petoro Ltd., established in 2001 to serve as an independent manager for the SDFI portfolio. 
Petoro Ltd has since managed SDFI on behalf of the State. Petoro is the licensee for production and those pipelines and land-based plants in which the State has a direct interest at any time. Petoro is not the owner of the SDFI shares on the Norwegian continental shelf, however. The value of the SDFI in 2006 was estimated at approximately USD 150 billion. There are other arm's-length regulatory agencies. One of these is Gassco Ltd., a state-owned corporation responsible for the transportation of natural gas from the Norwegian continental shelf. Gassnova Ltd., an administrative agency responsible for promoting and supporting innovation and development of environmentally friendly gas power technology, is another.

In 2007 Statoil ASA was fused with the limited state controlled corporation Norwegian Hydro, which is now by far the dominant actor on the Norwegian continental shelf but also a significant international actor in the petroleum sector. The State share of Statoil organised as a Private-Law Body diminished because of the merger, but the State is still the major and controlling shareholder. Now Statoil again is listed on both the Oslo and the New York stock exchanges.

As mentioned earlier, The Norwegian Petroleum Directorate is not an arm's-length body but a part of the government and as such reflects a petroleum sector with ordinary administration. The Directorate plays a major role in the management of the petroleum resources and is an important advisory body for the Ministry of Petroleum and Energy. It has the authority to issue regulations and control and to make decisions according to the rules and regulations for the petroleum industry.

The supervisory body of the competition system with regard to organisational matters and the surveillance of the liberalised European petroleum market is the regulatory EFTA Surveillance Authority (ESA). This authority functions in accordance with the EEA agreement between Norway and the EU. ESA is a general operating agency of the regulatory state order, mandated to perform the surveillance of legality regarding market competition, including in the petroleum sector.

\section{The arrival of the Norwegian Government Pension Fund - Global}

Many of the facts about the Government Pension Fund, its organisational features and the policy itself, presented here for descriptive purposes, are to be found in the Report No. 24 (2006-2007) to the Parliament (Stortinget) 'On the Management of the Government Pension Fund in 2006'.

\subsection{Purpose}

The Petroleum Fund was established in 1990 as a tool of fiscal policy in order to support the long-term regulatory management of the petroleum revenues. Typical for the regulatory state mode of governance, the Ministry of Finance is responsible for the management of the Government Pension Fund but has authorised the arm's-length Norwegian Central bank to be responsible for the operational management of the Pension Fund - Global. The Central Bank is accordingly organised as an independent governmental agency, which in this context invests the fund's capital in bonds and equities. Renaming the Petroleum Fund to the Pension Fund - Global in 2006 was actually part of a broader regulatory pension reform highlighting also the Fund's role in facilitating the governmental savings necessary to meet the expected rapid rise in public pension expenditures in the coming years, see Figure 2. The goal of this broader reform has been to slow down the rising expenditures by making it more profitable for people to stay longer in the work-force after reaching ordinary retirement age. This is called the 'work line reform'.

The Pension Fund is not earmarked for pension expenditures but is politically devoted to this social security objective. Politically, the Norwegian welfare state of the Nordic type, with universal social rights, is put into play in the global age, and future economies determine the rules of this game (Veggeland, 2007). Certainly, there exist risks to lose the game. However, to make goals about social equity and equality and expensive welfare arrangement realistic at all, the Pension Fund - Global constitutes a necessary and believed guaranty (Veggeland, 2009).

The Pension Fund is fully integrated into the budget of the national government. It functions as a tool to strengthen the budgetary process and builds on existing institutions. The Fund is only invested abroad in financial assets in order to bring the accumulated effective demand and inflation in the national economy under regulatory control. Investing abroad also ensures risk diversification in order to increase the chances of good financial returns and helps to protect the domestic non-petroleum economy.

The political intention of maintaining a high degree of transparency and disclosure of information through evaluation reports and public debate is not always realised (Reinertsen, 2008). Nevertheless, this openness to some extent helps to build public support and accountability that encourage the wise management of the petroleum 
revenues and reduce the risks of poor governance that can result in failing investments and of corruption when huge sums of money are in play.

\subsection{Key design features}

The Pension Fund's inflow consists of all state petroleum revenues, the net financial transactions related to petroleum activities, and the return on the Fund's investments. The outflow from the Fund is the sum needed to cover the deficit of the non-petroleum governmental budget. The net cash flow from the petroleum revenues comprises the total inflow minus the outflow, including pension expenditures, from the Fund.

This means that the Fund is fully integrated into the state budget and that net allocations to the Fund reflect the total budget surplus (including petroleum revenues). Fiscal policy, which regulates the outflow from the Fund, adheres to the guideline that the non-petroleum budgetary deficit should eventually correspond to a limited return from the Fund, estimated at 4 per cent. It is a responsibility of the Parliament to adopt budgets that do not exceed this limit.

We have already noted that the Ministry of Finance is responsible for the management of the Fund, and in line with the regulatory state mode of steering activities, the Norwegian Central Bank carries out the operational management. The Bank is obliged to invest innovatively and selectively the Fund money in accordance with the guidelines issued by the Ministry, and, as we shall elaborate later, in accordance with ethical guidelines. The Fund might now be named the Ethical Pension Fund.

All key changes to the investment guidelines are presented to the Parliament before implemented. The Ministry receives advice on the investment guidelines from Norwegian Central Bank, the Ministry's advisory council on investment strategy and external consultants. The Ministry also uses external consultants for the independent evaluation of performance and the benchmarking of performance and costs (Eriksen, 2006).

\subsection{Investment guidelines}

The investment strategy is to achieve high financial returns subject to moderate risk. The Pension Fund is only invested abroad in financial instruments. The Fund is a financial investor with a diversified portfolio of numerous investments in a range of companies. The Fund's financial results are primarily assessed in the terms of international currency in order to measure the development in the Fund's international purchasing power.

Equities account for 60 per cent of the Fund's strategic benchmark portfolio, comprising equities listed on exchanges in Europe (50 per cent), America and Africa (35 per cent) and Asia/Oceania (15 per cent). Fixed income instruments account for 40 per cent of the strategic benchmark portfolio, consisting of fixed income instruments issued in currencies from Europe ( 60 per cent), America/Africa ( 35 per cent) and Asia/Oceania ( 5 per cent) (Report No. 24 (2006-2007) to the Storting).

\subsection{Transparency}

The management of petroleum revenues in general and the Fund in particular is characterised, as already pointed out, by transparency and disclosure of information. These features are necessary because a high degree of transparency and openness is essential to be able to build accountability and support for the Government's management of the petroleum wealth. Large budgetary surpluses and substantial and very visible financial assets are in play, and this 'play' is also in need of taming under democratic control, besides being under regulatory control.

The Ministry reports to the Parliament on all important matters relating to the Fund, such as the size of petroleum revenues and the Fund, the outlook for fiscal sustainability, changes to the investment strategy, and the Fund's performance in relation to risk and costs. The Ministry also publishes advice and reports received from Norwegian Central Bank, the Strategy Council, and external consultants. Further, it publishes quarterly reports on the management of the Fund, as well as an annual report and an annual listing of all investments.

\section{Ethical Guidelines - A regulatory approach}

We have seen earlier the references to the economist Frédéric Lordon (2003) and his statements regarding the actual financial crisis and an anxious stock market. The title of his book is appropriately provocative: And virtue is going to save the world...After the financial catastrophe, the salvation by "ethics"? This idea may perhaps also have struck Norwegian politicians and social scientists. Whatever the case may be, in the framework of the regulatory state, the Government Pension Fund gives the option to pursue ethical taming in practical politics.

The Norwegian ethical guidelines were issued in December 2005, and, in accordance to the regulations on the Management of the Government Pension Fund - Global, formal regulations on the Management of the Government Petroleum Fund were issued in 2004. The recommendations of the Graver Commission (NOU, 2003, 
p. 22) form the basis for the guidelines for the Fund. Hans Petter Graver, the leader of the Commission, is not by chance a professor in law and an expert in EU regulations.

\subsection{Basis}

The ethical guidelines for the Government Pension Fund - Global are based on two official basic premises in a political and economic regulatory taming perspective:

- Economic ethical premise: 'The Government Pension Fund - Global is an instrument for ensuring that a reasonable portion of the country's petroleum wealth benefits future generations. The financial wealth must be managed so as to generate a sound return of revenues in the long term, which is contingent on sound and sustainable development in the economic, environmental, and social sense. The financial interests of the Fund shall be strengthened by using the Fund's ownership interests to promote such sustainable development'.

- $\quad$ Political ethical premise: 'The Government Pension Fund - Global should not make investments which constitute an unacceptable risk that the Fund may contribute to unethical acts or omissions, such as violations of fundamental humanitarian principles, serious violations of social and human rights, gross corruption or severe environmental damages'.

\subsection{Mechanisms}

The ethical basis for the Government Pension Fund - Global is to be promoted through the following three measures:

- Exercise of ownership rights in order to make sustainable investments globally, involving the diversification and dispersion of the investments both geographically and industrially to reduce risks and to secure stable revenues in the pursuit of long-term financial returns. Promotion of sustainability in every sense should be a goal in itself.

- Negative screening of companies from the investment universe that either themselves or through the firms they control violate fundamental social, humanitarian, and environmental principles.

- Exclusion of companies from the investment universe when either there have been violations of the aforementioned ethical principles or a risk is deemed unacceptable for the political and economic premises of the Pension Fund.

The overall objective of Norwegian Central Bank's exercise of ownership rights for the Government Pension Fund - Global is to safeguard the Fund's financial interests, because these interests represent the necessary conditions for revenues. And that is how the ownership rights should be exercised, as mentioned, a long-term horizon for the Fund's investments and a broad diversification of investments in the markets that are included in the investment universe. What about the ethical aspect of this regulatory petroleum regime through the perspective of governance?

The exercise of ownership rights is decidedly strongly bound to the UN's Global Compact and the OECD Guidelines for Corporate Governance and for Multinational Enterprises. The Central Bank's internal guidelines for the exercise of ownership rights indicate how these principles should be integrated in the ownership strategy (Austvik, 2007). Further, these regulatory bodies are supposed to be in charge of enforcing ethical conduct.

\subsection{Negative screening and exclusion}

Based on recommendations given by the Council on Ethics for the Government Pension Fund - Global, the Ministry of Finance is the authority responsible for making decisions on negative screening and exclusion of companies from the investment universe.

The recommendations and decisions are to be made public. The Ministry may, in certain cases, postpone the timing of public disclosure if this is deemed necessary in order to ensure a financially sustainable implementation of the exclusion of the company concerned.

The Council on Ethics for the Government Pension Fund - Global comprises five members; in 2008 these are two professors of law, one professor of philosophy, and two managing directors. The Council has its own secretariat. The Council submits an annual report on its activities to the Ministry of Finance. Both the Ministry's decisions and the Council's recommendations are made publicly available on the Council of Ethics website.

Upon request of the Ministry of Finance, the Council issues recommendations on whether or not an investment may constitute a violation of Norway's obligations under international law and may be in conflict with the ethical regulations. 
The Council is obliged to issue recommendations for negative screening of one or several companies in cases where the production of weapons through their normal use may violate fundamental humanitarian principles. The Council issues recommendations on the exclusion of one or several companies from the investment universe because of acts or omissions that constitute an unacceptable risk to the Fund (Council on Ethics, 2010):

Indicators:

- 'Serious or systematic human rights violations, such as murder, torture, deprivation of liberty, forced labour, the worst forms of child labour and other forms of child exploitation'.

- 'Serious violations of individuals' rights in situations of war or conflict'.

- 'Severe environmental damages'.

- 'Gross corruption'.

- 'Other particularly serious violations of fundamental ethical norms'.

The Council of Ethics is authorised to raise issues under these indicators on its own initiative or at the request of the Ministry of Finance.

Accordingly, the Council gathers all necessary information in order to ensure that the matter is documented as fully as possible before making a recommendation of negative screening or exclusion from the investment universe. This is, of course, a very complicated act and produces failures first and foremost because information often comes up more or less haphazardly (Reinertsen, 2008). The Council may request Norwegian Central Bank to help provide information on how specific companies are dealt with in the exercise of ownership rights. Enquiries to such companies are channelled through Norwegian Central Bank. If the Council is considering the recommendation of exclusion of a company, the company in question will receive the draft recommendation and the reasons for it in order to comment on it.

The Council has the duty to review on a regular basis whether the reasons for exclusion still apply and may recommend that the Ministry of Finance revoke a decision to exclude a company if new relevant information is uncovered.

The Norwegian Central Bank is the regulatory agency that receives immediate notification of the decisions made by the Ministry of Finance in connection with the Council's recommendations. The Ministry of Finance may request that the Norwegian Central Bank inform the companies concerned of the decisions taken by the Ministry and the reasons for the decision.

Table 2 provides a presentation of the results from the screening work done by the Council on Ethics for the Government Pension Fund - Global. Companies considered to have violated the ethical regulations and consequently excluded from the investment universe from 2005 to 2011.

\section{Vulnerability and risk analysis of the Norwegian Pension Fund - Global}

The vulnerabilities and risks in a political and economic perspective are manifold (Alm, 2010). Funding a pension system in the absence of a domestic budgetary surplus certainly has implications of political and economic risk, which is the case with the Norwegian Pension Fund. One implication is that more legal protection set by regulations is given to future pension payments than to other priorities and public outlays. This presents a challenging game in regard to short-term political legitimacy and politicians' re-election cycles. Future pension payments are set against instant investments in roads, schools, hospital services, etc., all of which are vital utilities that have to be set as lower priorities as a result This down-grading of important investments occurs because the pension-funding regime defines the rules of the game, and these rules count until they eventually get changed - and that is a risk.

The Norwegian Pension Fund - Global is also vulnerable in another sense. If future economic growth and governmental revenues turn out to be lower than expected, the negative consequences will fall primarily on public consumption, in accordance with the actual regulatory measures. As pointed out, the Pension Fund is not earmarked for any specific purpose; the intentions are only politically formulated, and the risk is that these might be changed. 'Politics of blame avoidance' (Weaver, 1986) may be the outcome for governments when coping with the effects of unexpected decreases in future revenues. Or the governments may feel the political pressure to prioritise greater domestic investment in the cost of the inflow in the Pension Fund or may change the arrangement by letting the petroleum revenues pass into the private sector, away from the goals of universal welfare and collective action. 


\subsection{Legitimacy and negative screening}

Another line of argument is bound to the regulatory state's thinking on legitimacy (Veggeland, 2009, 2011). The funding of the Pension Fund and the use of petroleum revenues according to laws and regulations, outside direct democratic control and not exposed to short-term political decision-making, is meant to increase the legitimacy and long-term protection of the Fund's assets. An often given example is the high public support for the protection of the assets in the Alaska Permanent Fund. Here, real money from the Fund is handed out directly to the citizens of Alaska. This policy does not, however, reduce vulnerability because it is a short-term perspective that has overrun enduring, long-term considerations regarding welfare and social security (Skancke, 2003).

We have previously reviewed the three taming measures that constitute the Norwegian Ethical Pension Fund. These are the exercise of ownership rights in order to make sustainable investments globally, diversifying and dispersing the investments geographically, industrially, and financially to reduce risks and secure stable revenues; the negative screening of companies from the global investment universe that either themselves or through the corporations they control violate fundamental social, humanitarian, and environmental principles; and the exclusion of companies when violations of the principles above have been revealed or when a company is considered to be an unacceptable risk to the political and economic premises for the Pension Fund.

First, there is the exercise of ownership and the strategic measures to reduce investment risks and to secure stable petroleum revenues. Obviously, the strategy of diversity and spreading investments geographically, industrially, and financially is an appropriate strategy. Technically, the Norwegian Central Bank can quite easily implement the strategy. Yet, this strategy does not remove vulnerability and risk (Reinertsen, 2008). The whole scheme depends on an international economy and a balanced and growing business cycle. Short-term sector problems and trade disturbances are but normal and acceptable, but an international economy undergoing a deep structural crisis is certainly not. But the history of economics tells us that such crises always have occurred from time to time, with the stagflation crisis from the 1970s and a looming international financial crisis in 2008 as the latest examples. Such crises have been a main subject for most of the classical economists - from Malthus and Marx to Keynes and Schumpeter (Veggeland, 2009). A future international structural crisis would probably be a catastrophe for the Norwegian Government Pension Fund.

\subsection{Ethical challenges}

Secondly, it is questionable whether the negative screening and exclusion of companies violating the ethical guidelines for Pension Fund investments is sufficiently feasible to affect policy (Alm, 2010). The list of excluded corporations, Tab. 2, shows that implementation of the ethical guidelines and regulations are feasible. The problem is, however, that a fair and accountable screening of corporations in this context is very unreliable, perhaps with a high risk for overlooking the worst cases (Reinertsen, 2008). Globally, the transparency of economic networks is very low. Enormous human and technical resources have to be reserved for the task of penetrating these networks and looking for grounds for ethical disqualification regarding investments. One has to be aware of that such use of resources from the Norwegian Pension Fund - Global is not a reality today.

In the future, we may assume that the Norwegian Pension Fund will face huge challenges connected to international agreements on environmental issues, i.e., regulations that intend to restore ecological systems and to secure sustainable development. This is good from a human and ethical development perspective, but it might reduce the expected high revenues from the petroleum industry. Certainly, global agreements on environmental issues imply strong regulations on the exploration, production, and refining of petroleum in the future. In conclusion, the Norwegian Pension Fund is also vulnerable in that environmental threats challenge the petroleum revenues and therefore also the predicted high net inflow of money into the future Fund.

\section{What does Norway get out of the GPF-G? The dilemma: foreign investments versus domestic investments}

"What does Norway get out of its Oil Fund (Government Pension Fund - Global (GPF-G)), if not More Strategic Infrastructure Investment, is Michael Hudson asking" (Hudson, 2011). He keeps on asking: "What do Norwegians get out of these financial savings, besides a modest interest and dividend yield? The export surplus is said to be too large to spend more than a small fraction (a Procrustean 4 percent) at home without causing inflation"? So other countries get not only Norway's petroleum, but also most of the royalties and earnings from its production. Meanwhile, Norway spends little on itself. Even now that its financial managers are beginning to worry about how risky the stock markets are becoming and feel the need to diversify into real estate, the Norwegian government still avoid investing the Pension Fund's wealth to build up the domestic infrastructure. His critical analysis goes further like this. 


\subsection{Passive and active approaches}

What seems ironic is that while Norway is sending its savings mainly to European and U.S. financial markets, money managers in these countries are sending their funds to the BRIC economies (Brazil, Russia, India and China). This broad scope invests export earnings directly to make their economies more competitive while raising living standards. This also points to the fact that dealing with the Pension Fund goes beyond the purely financial scope of deciding simply what foreign stocks and bonds to buy. The basic financial scope of question is which securities will achieve the highest rate of return or rise most quickly in price. This is a short-term decision. Little of this financial acrobatic policy adds value to the real capital of the Norwegian economy.

Given this situation, how should Norway best policy look like? As a point of departure, the Norwegian government has a broader option than merely to steer savings into foreign financial markets. The policy should improve the economy by creating tangible means of production to raise productivity by working in tandem with leading national industries, generate innovation by give investment in research priorities, and favor building infrastructure, social as well as physical infrastructure. And rather than being inflationary, public investment enabled economies to minimize their cost of living and doing business.

There are two approaches to how the Norwegian government may manage their Pension Fund - Global. For simplicity, these can be called the passive and active approaches. The present approach is passive. Norway consigns its petroleum "earnings to money managers to buy stock or bond ownership abroad without linking these purchases to its own future development - except by receiving a modest foreign exchange return" (Hudson, 2011, p. 3). The more active approach considers the government's duty as being to develop the domestic economy to the benefit of its citizens. This is done by initiating infrastructure building, including education and public health care, research and development, and investment in transportation, power generation and distribution, communications and information technology.

\subsection{Real capital neglected}

Public infrastructure represents the largest capital expenditure in almost every country, yet little trace of its economic role appears in today's Norwegian income and product accounts. Free market ideology wrongly treats public spending as deadweight, and counts infrastructure spending as part of the deficit, not as productive capital investment. Nobel Prize winner 1989, Trygve Haavelmo from Norway, describes the aim of public investment as being different from that of individuals or business. The ultimate aim was not to seek profits, but to create the best economic and social system possible with the resources at hand.

As the Norwegian Prime Minister (PM) since 2005, Jens Stoltenberg, an economist and former Minister of Finance, actually he is a main architect behind the Norwegian Pension Fund - Global (of US \$584 bill) and "the budget rule" of not spending more than "an estimated return" of $4 \%$ pro annum. His main argument is that the fund's passive strategy of today is spreading the risk into a multitude of minority positions, and that therefore Hudson's advice of an active strategy and to concentrate investments in national strategic infrastructure and technology will increase the risk rather than reduce the risk. Probably Hudson will respond by arguing that apparently the PM has not understood the industrial motivation of real economic investment (real wealth creation) for Hudson's suggestion as opposed to the financial motivation (monetary profit) that he himself pursues. Monetary profit motivates the Pension Fund's investment in stock and bonds global, while domestic wealth creation is passed over by the PM.

The Norwegian government downgrades the monetary profit motive. Instead the Government argues that the potential threat of increased domestic investments will make the Norwegian currency harder against foreign currencies combined with a growing interest rate. The result of this will be loss of economic competiveness internationally.

\section{What does Norway get out of the GPF-G? The dilemma of negative ethical exclusion versus positive selection}

Thus far, the Ethical Council which monitors the Government Pension Fund - Global (GPF-G) investments has sought to meet its ethical objectives through so-called negative selection, i.e. exclusion of companies for unethical behavior picked out from the large universe of investments. As we see from tab. 2, these may be companies that violate human rights, use child labor, fail to observe ordinary standards for employee rights, manufacture nuclear weapons or cluster munitions, are responsible for severe environmental damage, etc.

Ethical management of the GPF-G could be exercised in two different manners; by negative exclusion or positive selection. For some years now, in the public debate, it has been proposed that the ethical management should be reoriented from negative screening to positive selection. Instead of excluding companies that violate the decided 
ethical standards, one should invest only in companies and branches that appear to be, in some sense, an active force for the good on ethical issues. Thus, T. Johnsen and O. Gjølberg $(2009$, p. 2) write:

... positive selection involves a significant narrowing of the investment universe. It is, generally speaking, much more difficult to declare a company to be completely without blame than completely beyond the realm of the ethically acceptable. The potential fallout from error under a pure positive selection strategy may also be much higher than under a negative selection strategy.

\subsection{Alternatives suggested}

Of course, they are right, and consequently Norway has chosen the easiest way; negative exclusion. Following up their conclusion, Johnsen and Gjølberg suggest a number of more pragmatic approaches that could be realized by decisions in the Ethical Council. One such approach they suggest for Norway is the "popular principle" of selecting positively the best-in-class strategy. This principle, they postulate, entails selecting those companies that are perceived, based on various ethical criteria, to be best in their class of type-production. The class may be defined as an industry (energy, consumer goods, finance, etc.), but it is also possible to define classes as type-production dominant for a particular region. This indicates that a firm may be the best in an ethical poor class, and should be rewarded with investments, and another relatively good ethical firm may be far from the top of the elite ethical and sustainable class of type-production, and investment should be withdrawn. This ranking principle as a pragmatic approach to the political will of realize positive selection more strongly has never been accepted in Norway as a policy for the GPF-G and ethical investments. The reason for that seems to be the problem of ranking. In the jungle of firms and branches it is almost technically impossible to figure out indicators, criteria and measures to make the ranking relevant.

What actually is a more relevant policy approach for Norway in this context is that criteria have been introduced in recent years which are directed investments for stimulating the growth of upcoming of pioneering firms and branches which concentrate on sustainable production for the future. Thus, in line with international trends, the criteria, the Fund favors in particular investment in companies within environmental technology, solar energy, and renewable energy in general, etc. The literature often refers to these criteria as 'pioneer screening'. Such selection strategies are premised on the idea that companies that make a positive contribution to the climate - or to the fight against AIDS and malaria - generate positive ethical externalities. Of course, this pioneering screening policy is not an unproblematic one. Obviously, new ethical conflicts or dilemmas may arise. When eventually the pioneering type-production becomes a commercial success in the global market normally and most likely negative externalities of ethical relevance arise. A randomly chosen example is given by Johnsen and Gjølberg: Pioneering screening can trigger investments in a pharmaceutical company that devotes a large share of R\&D resources on developing a low price anti-malaria drug that is affordable for poor people in Africa. NPF-G supports such investments. However, this company may at the same time be conducting large-scale animal testing or producing unhealthy drugs.

In the Norwegian debate on the GPF-G it has also been proposed that the management of the Fund should focus on investments for helping forward economic growth and poverty alleviation in developing countries. This perspective contains interesting views and raise entirely new ethical issues and challenges, in particular as far as positive selection is concerned. It is regrettable, but corruption and poverty do tend to co-exist, making it difficult to combine positive selection based on a company's ethical track-record and investments in developing countries. As observed and for the corruption problem, the NPF-G's positive selection is therefore often biased in favor of well-established, large companies in the rich countries.

\section{Summary}

The systematic risk of the type found in the Norwegian Pension Fund - Global has been discussed at length in this study and in the financial literature generally. It has become common to relate systematic vulnerability and risk to a wide range of factors that might cause imbalance and failure. Ulrich Beck (1992) postulates that risks today have a different significance for everyday life from the risks that applied to previous historical eras. He claims that human activity and technology in advanced political and economic modernity produce as a side-effect risks that demand specialised expertise in order to recognise them, and are collective, global, and irreversible in their impact. The Norwegian petroleum activity under regulatory management and control is such an example.

The Government Report No. 24 (2006-2007) to the Parliament (Stortinget), 'On the Management of the Government Pension Fund', has presented a very optimistic view on the risks involved. Taking as a point of departure that the risk-return profile of the Pension Fund is largely determined by the governmental investment guidelines, the report states that, 'The risk assumed in active management has only to a limited degree increased the actual market risk of the Fund...' (Government Report No. 24 (2006-2007), p. 82). 
There is, however, no simple way of conceiving risk-regulation regimes. No one has ever seen a risk-regulation regime embracing a totality of effects - and side-effects - along all dimensions. Against this background, Christopher Hood, Henry Rothstein, and Robert Baldwin have stated that, "principles that have been advanced for regulatory assessment typically comprise some mix of "economic rationalist" cost-effectiveness criteria together with rule-of-law criteria - such as proportionality and transparency - and policy evaluation to identify regulatory impacts and alternatives' (2001, p. 179).

We can recognise the meaning of this quotation in the Norwegian Petroleum industry and the establishment of the Pension Fund. With regard to the optimistic view on risk occurrence and the Pension Fund cited from the Government, as we have seen, there are good reasons to doubt this low assessment of the market risk of the Pension Fund. We should ignore neither the regular cycle of global economic crises nor the connection between global warming and $\mathrm{CO}_{2}$ emissions from petroleum activities, which is excluded from risk assessments.

The notion of 'actual market risks' with regard to the future of the Government (Ethical) Pension Fund - Global is far too narrow for a sufficient evaluation in the service of the common good. In a political and ethical perspective, the GPF-G should not, by definition, and unlike other ordinary international investment funds, represent risk capital in the terms of neo-classical liberal economic thinking. Substantial regulations by law and ethics deviate from regulations by the market.

Besides, the dilemma persists. Public infrastructure represents the largest capital expenditure in almost every country, yet little trace of its economic role appears in today's Norwegian income and product accounts. The investments are made abroad. The main arguments are two-fold and refer to a dilemma: the Fund's passive strategy of today is spreading the risk into a multitude of minority positions, and heavier domestic investments would trigger inflationary problems. Altogether, the Norwegian petroleum policy rests on the suggestion that an active strategy to concentrate investments in national strategic infrastructure and technology will increase rather than reduce the risk. This study reveals that some aspects of Norway's regulation of its petroleum industry and revenues tell a successful story, but several dilemmas remain unsolved.

\section{References}

Alm, K. (2010). The Norwegian Pension Fund: An Ethical Gold Standard for International Climatic Investments. In N. Veggeland (ed.), Innovative Regulatory Approaches Coping with Scandinavian and European Union Policies (pp. 131-147). New York: Nova Science Publishers.

Austvik, O. G. (2003). Norwegian Natural Gas. Liberalization of the European Gas Market. Oslo: Europa-programmet.

Beck, U. (1992). Risk Society: Towards a New Modernity. London: Sage.

Council on Ethics, Norwegian Government Pension Fund Global. (2010). Guidelines for the observation and exclusion of companies from the Government Pension Fund Global's investment universe. [Online] Available: http://www.regjeringen.no/en/sub/styrer-rad-utvalg/ethics_council/ethical-guidelines.html?id=425277 (March 1, 2010)

Eriksen, T. (2006). The Norwegian Petroleum Sector and the Government Pension Fund - Global, Paper. Ministry of Finance, Norway.

Government of Norway, Long-Term-Program 2002-2005. Oslo-dep.

Hood, C., Rothstein, H., \& Baldwin, R. (2004). The Government of Risk: Understanding Risk Regulation Regimes. Oxford: Oxford University Press.

Hudson, M. (2011). What Does Norway Get Out Of Its Oil Fund, if Not More Strategic Infrastructure Investment? Working Paper No. 657, Levy Economics Institute of Bard College.

Johnsen, T., \& Gjølberg, O. (2009). Management of Norwegian Oil Fund: The Challenges and Costs of Being Ethical, Beta 01/2009

Lordon, F. (2003). Et la vertu sauvera le monde: Après la débâcle financière le salut par l'éthique? [And virtue will save the world: salvation through ethics after the crash ?] Paris: Raisons d'agir.

National Budget. (2008). Presentation of the Government Pension Fund - Global, Section 5.3. Ministry of Finance, Norway.

National Budget. (2010). Presentation of the Government Pension Fund - Global. Ministry of Finance, Norway.

Reinertsen, M. (2008, July 11). 'Ondskapens aksjer' [Evil's shares], Article, Morgenbladet. 
Report No 24. to the Storting. (2006-2007). On the Management of the Government Pension Fund in 2006. Ministry of Finance, Norway.

Report no. 22. to the Storting. (2003). Forvaltning for fremtiden [Management for the future]. Ministry of Finance, Norway.

Report No. 29 to the Storting. (2000-2001). Guidelines for economic policy. Ministry of Finance, Norway.

Report No. 38 to the Storting. (2001-2002). Oil and Gas Activities. Ministry of Petroleum and Energy, Norway.

Skancke, M. (2003). Fiscal Policy and Petroleum Fund Management in Norway. In J.M. Davis, R. Ossowski \& A. Fedelino (eds.), Fiscal policy formulation and implementation in oil-producing countries (pp. 316-338). Washington, D. C.: International Monetary Fund.

Veggeland, N. (2007). Paths of Public Innovation in the Global Age: Lessons from Scandinavia. Cheltenham: Edward Elgar.

Veggeland, Noralv. (2009). Taming the Regulatory State. Politics and Ethics. Cheltenham, UK - Northampton, MA, USA: Edward Elgar.

Veggeland, Noralv. (2011). Den nye reguleringsstaten. Idébrytninger og styringskonflikter. (The New Regulatory State. Conflicting ideas and governance trends), Oslo: Gyldendal Akademisk.

Weaver, Robert K. (1986). The Politics of Blame Avoidance. Journal of Public Policy, 6 (4). http://dx.doi.org/10.1017/S0143814X00004219

Table 1. The large Norwegian petroleum revenues in 1000 billions that have resulted in substantial financial assets in what is now called the Government Pension Fund - Global

\begin{tabular}{|l|l|l|l|l|}
\hline Years & $\mathbf{2 0 0 5}$ & $\mathbf{2 0 0 6}$ & $\mathbf{2 0 0 7}$ & $\mathbf{2 0 1 0}$ \\
\hline Size in NOK bn & 1399 & 1784 & 2019 & 3500 \\
Size in USD bn & 207 & 285 & 373 & 584 \\
Total return in \% & 11.1 & 7.9 & 4.3 & 5 \\
Net real return in \% & 8.5 & 5.6 & 1.1 & \\
\hline
\end{tabular}


Table 2. Companies excluded from the investment universe since 2005

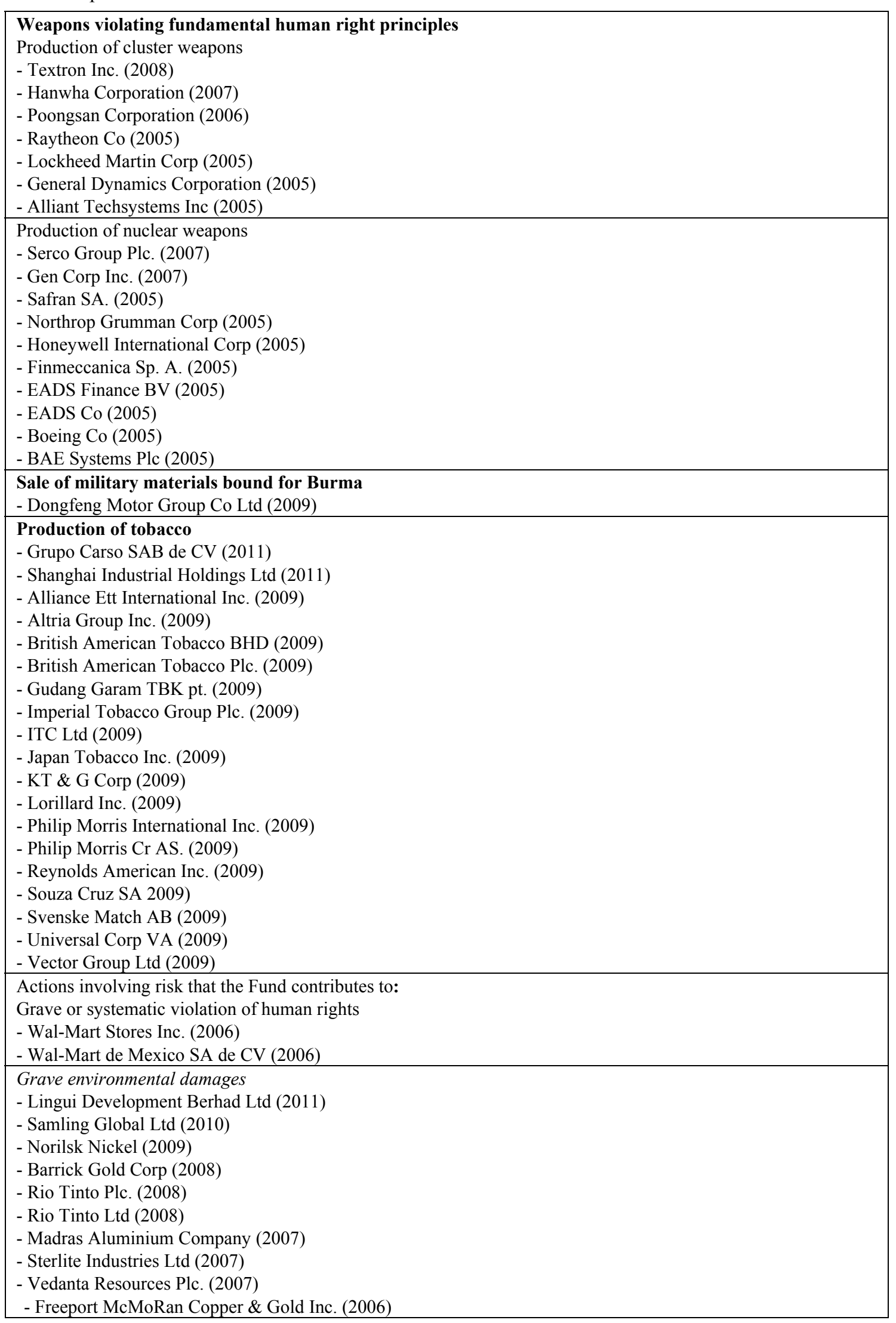




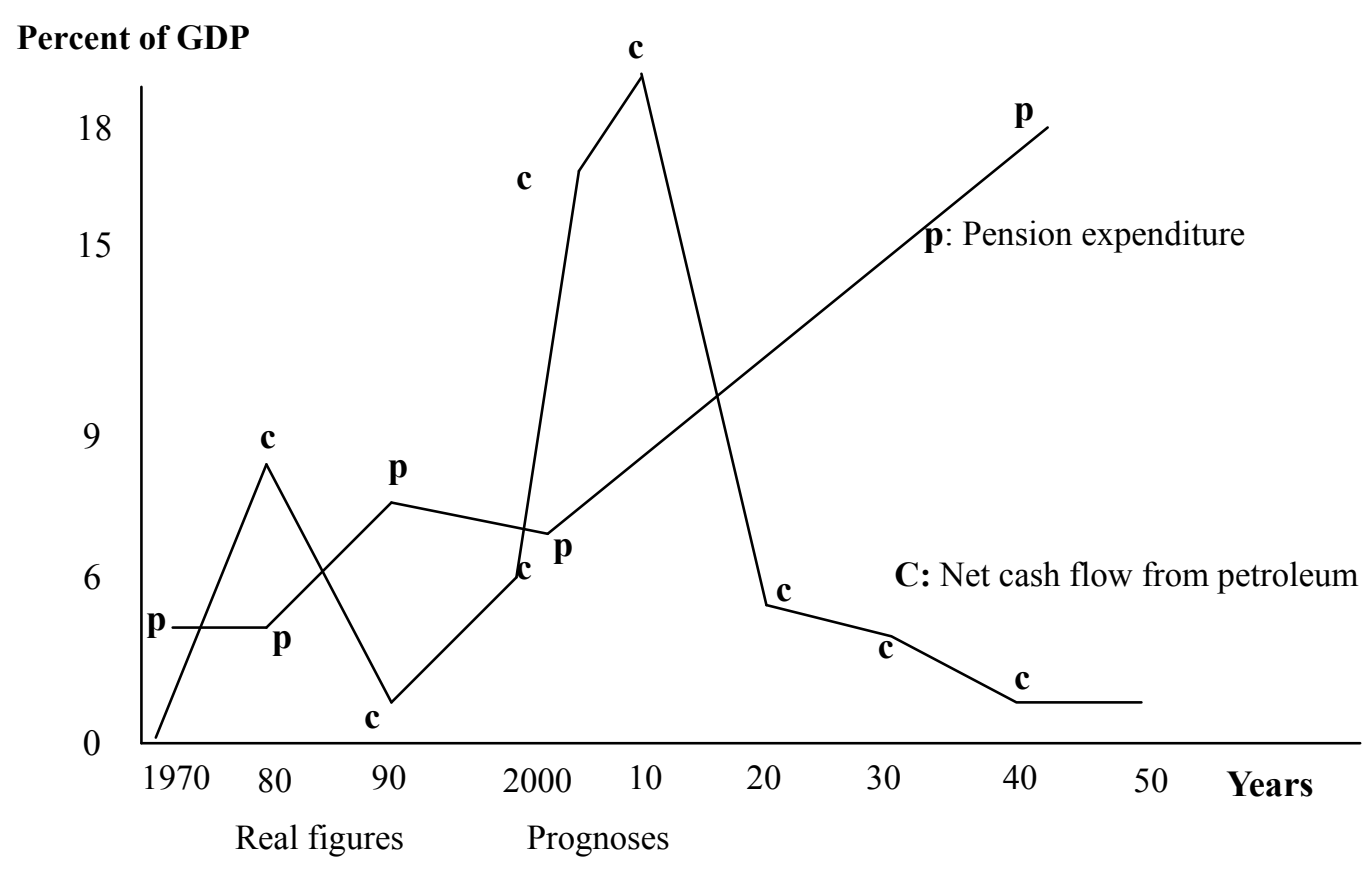

Figure 1. Net Cash Flow from Norwegian Petroleum and the Pension Expenditure (in per cent of GDP) Source: Government of Norway, Long-Term Program, 2002-05, simplified figure.

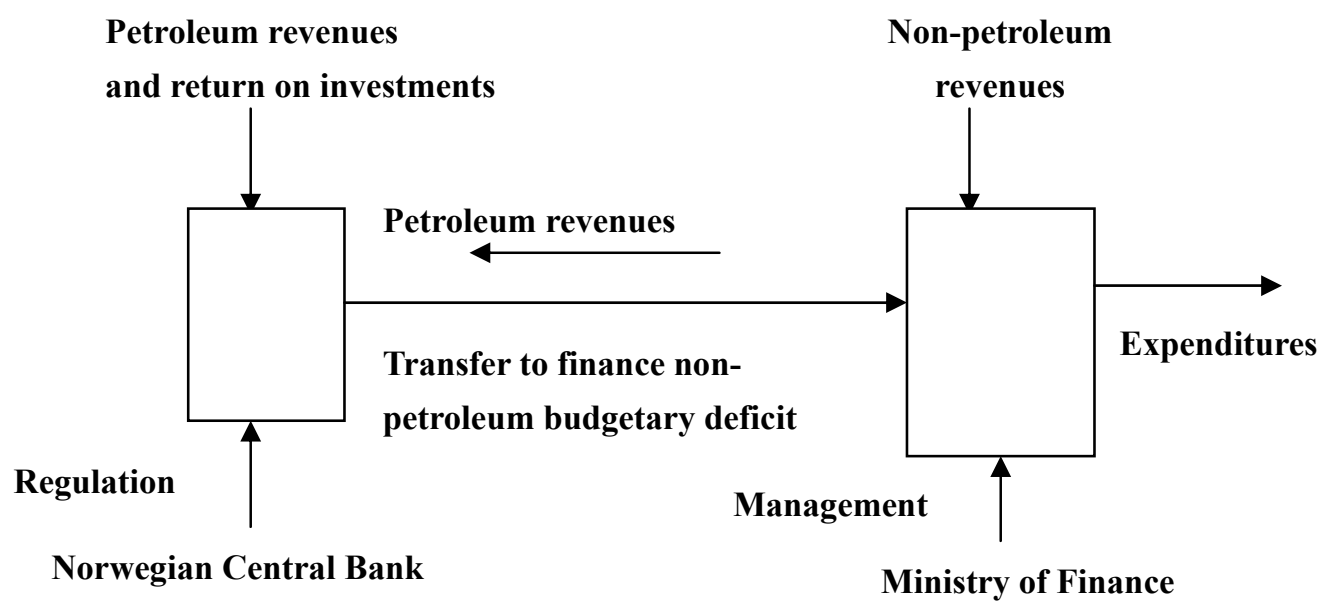

Figure 2. The Norwegian Pension Fund Mechanisms and organizational structure Source: www.regjeringen/pensjonsfondet.no 